eliminating tariff and non-tariff barriers to trade and investment, and opening markets; Business Facilitation-reducing the costs of business transactions, improving access to trade information and co-ordinating policy and business strategies to facilitate growth, and free and open trade; Economic and Technical Co-operation-assisting member economies build the necessary capacities to take advantage of global trade and the new economy. In 2012 Russia hosted APEC meetings under the theme 'Integrate to Grow, Integrate to Prosper'. The host for 2013 is Indonesia, using the theme 'Resilient Asia-Pacific, Engine of Global Growth’.

Official language: English.

Headquarters: 35 Heng Mui Keng Terrace, Singapore 119616.

Website: http://www.apec.org

Executive Director: Allan Bollard (New Zealand).

\section{Association of South East Asian Nations (ASEAN)}

History and Membership. ASEAN is a regional intergovernmental organization formed by the governments of Indonesia, Malaysia, the Philippines, Singapore and Thailand through the Bangkok Declaration which was signed by their foreign ministers on 8 Aug. 1967. Brunei joined in 1984, Vietnam in 1995, Laos and Myanmar in 1997 and Cambodia in 1999. Papua New Guinea also has observer status. The ASEAN Charter, signed in Nov. 2007, established the group as a legal entity and created permanent representation for members at its secretariat in Jakarta.

Objectives. The main objectives are to accelerate economic growth, social progress and cultural development, to promote active collaboration and mutual assistance in matters of common interest, to ensure the political and economic stability of the South East Asian region, and to maintain close co-operation with existing international and regional organizations with similar aims.

Activities. Principal projects concern economic co-operation and development, with the intensification of intra-ASEAN and global trade; joint research and technological programmes; co-operation in transportation and communications; promotion of tourism, South East Asian studies, cultural, scientific, educational and administrative exchanges. An ASEAN Free Trade Area (AFTA) agreement was signed in 1992. ASEAN member countries have in the meantime made significant progress in the lowering of intraregional tariffs through the Common Effective Preferential Tariff (CEPT) Scheme for AFTA. The ASEAN Charter of 2007 established a schedule for the elimination of non-tariff barriers and other restrictions on trade. On 1 Jan. 2010 ASEAN signed a free trade agreement with China, creating the world's largest free trade area by population (encompassing $1.9 \mathrm{bn}$. people) and the third largest by economic value.

Heads of government who met in Bangkok in Dec. 1995 established a South-East Asia Nuclear-Free Zone, which was extended to cover offshore economic exclusion zones. Individual signatories were to decide whether to allow port visits or transportation of nuclear weapons by foreign powers through territorial waters. The first formal meeting of the ASEAN Regional Forum ( $A R F$ ) to discuss security issues in the region took place in July 1994 and was attended by the then six members (Brunei, Indonesia, Malaysia, Philippines, Singapore and Thailand). Also in attendance were ASEAN's dialogue partners (Australia, Canada, the EU, Japan, South Korea, New Zealand and the USA), consultative partners (China and Russia) and observers (Laos, Papua New Guinea and Vietnam). In 2012 the participants in the ARF were the ten ASEAN members, Australia, Bangladesh,
Canada, China, the EU, India, Japan, North Korea, South Korea, Mongolia, New Zealand, Pakistan, Papua New Guinea, Russia, Sri Lanka, Timor-Leste and the USA.

ASEAN is committed to resolving the dispute over sovereignty of the Spratly Islands, a group of more than 100 small islands and reefs in the South China Sea. Some or all of the largely uninhabited islands have been claimed by Brunei, China, Malaysia, the Philippines, Taiwan and Vietnam. The disputed areas have oil and gas resources.

Organization. The highest authority is the meeting of Heads of Government, which takes place twice annually. The highest policy-making body is the annual Meeting of Foreign Ministers, commonly known as AMM, the ASEAN Ministerial Meeting, which convenes in each of the member countries on a rotational basis in alphabetical order. The AEM (ASEAN Economic Meeting) meets each year to direct ASEAN economic cooperation. The AEM and AMM report jointly to the heads of government at summit meetings. The central secretariat in Jakarta is headed by the Secretary-General, a post that revolves among the member states in alphabetical order every five years.

Official language: English.

Headquarters: 70A Jl. Sisingamangaraja, Jakarta 12110, Indonesia.

Website: http://www.asean.org

Secretary-General: Le Luong Minh (Vietnam).

\section{ASEAN-Mekong Basin Development Co-operation (Mekong Group)}

The ministers and representatives of Brunei, Cambodia, China, Indonesia, Laos, Malaysia, Myanmar, Philippines, Singapore, Thailand and Vietnam met in Kuala Lumpur on 17 June 1996 and agreed the following objectives for the Group: to co-operate in the economic and social development of the Mekong Basin area and strengthen the link between it and ASEAN member countries, through a process of dialogue and common project identification.

Priorities include: development of infrastructure capacities in the fields of transport, telecommunications, irrigation and energy; development of trade and investment-generating activities; development of the agricultural sector to enhance production; sustainable development of forestry resources and development of mineral resources; development of the industrial sector, especially small to medium enterprises; development of tourism; human resource development and support for training; co-operation in the fields of science and technology.

\section{Further Reading}

Beeson, Mark, Regionalism \& Globalization in East Asia: Politics, Security \& Economic Development. 2006.-Contemporary Southeast Asia. 2nd ed. 2008.-Institutions of the Asia-Pacific: ASEAN, APEC and Beyond. 2008

Broinowski, A., Understanding ASEAN. 1982.-(ed.) ASEAN into the 1990s. 1990

Jarvis, Darryl S. L. and Welch, Anthony, (eds.) ASEAN Industries and the Challenge from China. 2011

Jones, Lee, ASEAN, Sovereignty and Intervention in Southeast Asia. 2011

Lee, Yoong Yoong, ASEAN Matters! Reflecting on the Association of Southeast Asian Nations. 2011

\section{Colombo Plan}

History. Founded in 1950 to promote the development of newly independent Asian member countries, the Colombo Plan has grown from a group of seven Commonwealth nations into an 